УДК 616-08-039.75

DOI: $10.18101 / 2306-1995-2019-1-39-43$

\title{
РАЗВИТИЕ АМБУЛАТОРНОЙ ПАЛЛИАТИВНОЙ ПОМОЩИ ДЕТЯМ И ПОДРОСТКАМ В РЕСПУБЛИКЕ БУРЯТИЯ
}

\author{
(C) Жданова Лариса Владимировна \\ кандидат медицинских наук, доцент, \\ кафедра акушерства и гинекологии с курсом педиатрии, \\ Бурятский государственный университет им. Д. Банзарова \\ Россия, 670000, Улан-Удэ, ул. Октябрьская, 36а \\ E-mail: 1.zhdanova@mail.ru \\ (C) Лебедева Ольга Александровна \\ заведующая, отделение паллиативной помощи детям \\ городская поликлиника № 2 \\ Россия, 670031, Улан-Удэ, ул. Геологическая, д. 23 \\ E-mail: rusinovata@gp2rb.ru

\section{(C) Колмакова Виктория Викторовна} \\ главный врач, \\ городская поликлиника № 2 \\ Россия, 670031, Улан-Удэ, ул. Геологическая, д. 23 \\ E-mail: priem@gp2rb.ru

\section{(C) Русинова Татьяна Антоновна} \\ заместитель главного врача, \\ городская поликлиника № 2 \\ Россия, 670031, Улан-Удэ, ул. Геологическая, д. 23 \\ E-mail: rusinovata@gp2rb.ru
}

Целью нашего исследования было изучить показатели эффективности работы паллиативной медицинской службы детям на дому в Республики Бурятия. В основу работы положен отчет работы патронажной службы паллиативной медицинской помощи детям в «Городской поликлинике № 2». В Республики Бурятия 4955 детей инвалидов, из них 5\% нуждаются в паллиативной медицинской помощи. Сегодня на обслуживании выездной службы состоит 114 детей. Большее количество детей это дети от 0 до 14 лет. Наибольшее число случаев (80\%) относится к заболеваниям нервной системы. На втором месте врожденные пороки развития и генетическая патология. С онкопатологией дети получают специализированную паллиативную помощь в условиях Детской республиканской клинической больницы. За 2018год было 34 ребенка, имеющие показания для оказания данного вида медицинской помощи. За все годы существования патронажной службы умерло 14детей.

Ключевые слова: паллиативная медицинская помощь, дети.

Для цитирования:

Жданова Л. В., Лебедева О. А., Колмакова В. В., Русинова Т. А. Развитие амбулаторной паллиативной помощи детям и подросткам в Республике Бурятия // Вестник Бурятского государственного университета. Медицина и фармация. 2019. Вып. 1. С. 39-43. 


\section{Введение}

Развитию паллиативной помощи в Российской Федерации способствовал Федеральный закон от 21.01.2011 г. Ф3-323 «Об охране здоровья граждан в Российской Федерации», который определил новый вид медицинской помощи паллиативную медицинскую помощь, как комплекс медицинских вмешательств, направленных на избавление от боли и облегчения других тяжелых проявлений заболевания, в целях улучшения качества жизни неизлечимо больных граждан [1]. С данного момента оказание паллиативной помощи стала рассматриваться на государственном уровне, и она включена в программу государственных гарантий.

Паллиативная медицинская помощь детям в Республики Бурятия организована согласноприказу МЗ РБ № 1790-ОД от 29.12.2015 г. «Об организации оказания паллиативной медицинской помощи детям на территории Республика Бурятия». В структуре имеются выездная патронажная служба паллиативной медицинской помощи детям, круглосуточная стационарная паллиативная помощь, последняя организована на базе в ГАУЗ «Детская республиканская клиническая больница» и имеет в своем составе 2 койки и на базе ГАУЗ «Детская клиническая больница с центром медицинской реабилитации» на 5 коек.

В Республики Бурятия большое значение уделяется организации амбулаторной паллиативной помощи детям, поскольку данный вид создает максимально комфортные условиях для тяжелобольного ребенка и членов его семьи. Амбулаторная паллиативная медицинская помощь создана на основании приказа № 53 от 18.02.2016 г. ГАУЗ «Городская поликлиника № 2» и функционирует с марта 2016 года.

Цель исследования: изучить показатели эффективности работы паллиативной медицинской службы детям на дому в Республики Бурятия.

Материалы и методы исследования: отчет работы патронажной службы паллиативной медицинской помощи детям ГАУЗ «Городская поликлиника № 2».

Результаты исследования: В Республики Бурятия 4955 детей инвалидов, из них 5\% нуждаются в паллиативной медицинской помощи. На момент создания патронажной службы в Республики Бурятия в регистре пациентов нуждающихся в оказании паллиативной помощи было 84 ребенка, сегодня на обслуживании выездной службы состоит 114 детей (табл. 1).

Таблийа 1

Количество детей нуждающихся в оказании паллиативной помощи

\begin{tabular}{|c|c|c|c|c|c|c|c|c|c|c|c|}
\hline № ЛПУ & $\begin{array}{l}\Gamma \Pi \text { № } \\
1\end{array}$ & $\begin{array}{l}\text { ГП } \\
\text { № } 2\end{array}$ & $\begin{array}{l}\text { ГП } \\
\text { № } 3\end{array}$ & $\begin{array}{l}\text { ГБ } \\
\text { № } 4\end{array}$ & $\begin{array}{l}\text { ГБ } \\
\text { № } 5\end{array}$ & $\begin{array}{l}\text { ГП } \\
\text { № } 6\end{array}$ & 1 & 2 & 3 & 4 & 5 \\
\hline 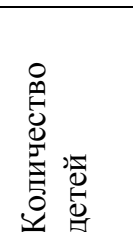 & 6 & 26 & 22 & 10 & 7 & 19 & 5 & 1 & 2 & 1 & 5 \\
\hline
\end{tabular}

Примечание: 1 - Заиграевский р-он, 2 - Тарбагатайский р-он, 3 - Иволгинский p-он, 4 - Кяхтинский, p-он, 5 - реабилитационный центр «Журавушка» 
Л. В. Жданова $и$ m. д. Развитие амбулаторной паллиативной помощи детям и подросткам в Республике Бурятия

Возрастная структура детей, получающих паллиативную помощь в целом, не отличается от таковой в Российской Федерации. Наибольшая возрастная представленность - это дети от 0 до 14 лет, при этом 44,8\% дети младшего школьного возраста (табл. 2).

Таблиц̧а 2

Возрастная структура детей, получающих амбулаторную паллиативную медицинскую помощь

\begin{tabular}{|c|c|}
\hline Возраст & Кол-во \\
\hline До года & 1 \\
\hline $1-4$ лет & 27 \\
\hline $5-9$ лет & 25 \\
\hline $10-14$ лет & 43 \\
\hline $15-18$ лет & 18 \\
\hline
\end{tabular}

За все годы существования патронажной службы умерло 14 детей. В целом количество умирающих детей невелико, по сравнению со взрослыми, но отмечено увеличение количества детей, нуждающихся в паллиативной медицинской помощи.

Заболевания детей, нуждающихся в паллиативной помощи разнообразны. Общепринято делить детей на две группы - со злокачественными новообразованиями и незлокачественными (неонкологическими заболеваниями). С онкопатологией дети получают специализированную паллиативную помощь в условиях Детской республиканской клинической больницы. За 2018 год было 34 ребенка, имеющие показания для оказания данного вида медицинской помощи.

Нозология детей с незлокачественными заболеваниями представлена в таблице №3.

Таблицча 3

Нозологическая структура детей, получающих амбулаторную паллиативную медицинскую помощь

\begin{tabular}{|l|c|c|}
\hline \multicolumn{1}{|c|}{ Диагноз } & $\begin{array}{c}\text { Количество } \\
\text { детей }\end{array}$ & Удельный вес \% \\
\hline Заболевания нервной системы & 91 & $80 \%$ \\
\hline Из них: & & $60 \%$ \\
\hline ДЦП & 68 & $7,9 \%$ \\
\hline Гидроцефалия & 13 & $11,4 \%$ \\
\hline Эпилепсия & 2 & $1,7 \%$ \\
\hline Последствия нейроинфекции & 1 & $0,8 \%$ \\
\hline Миопатия Дюшена & 2 & $1,7 \%$ \\
\hline Спинальная амиотрофия & 15 & $13 \%$ \\
\hline $\begin{array}{l}\text { Врожденные пороки развития и генети- } \\
\text { ческая патология }\end{array}$ & 3 & $2,6 \%$ \\
\hline Последствия травм & 1 & $0,8 \%$ \\
\hline Бронхо-легочная дисплазия & 114 & $100 \%$ \\
\hline Всего & & \\
\hline
\end{tabular}

Наибольшее число случаев (80\%) относится к заболеваниям нервной системы. На втором месте врожденные пороки развития и генетическая патология. В Российской Федерации структура нозологий выглядит иначе. Наибольшее число 
случаев относится к врожденным аномалиям, деформациям и хромосомным нарушениям. На втором месте по частоте находятся нозологические формы, относящиеся к классу болезней нервной системы [2]. Данную разницу трудно оценить, но, не исключается, что в Республики Бурятия большое количество детей генетическими заболеваниями и хромосомными нарушениями проживают в отдаленных районах республики, и не зарегистрированы в регистре детей, получающих паллиативную помощь.

Организация паллиативной помощи на дому включает множество функций - организация специализированной медицинской помощи, оказание психологической поддержки, терапия боли, обеспечение лекарственными препаратами. Более 2 тыс. посещений в год выполняется специалистами патронажной службой, которые на дому проводят перевязки, обработку стом, установку катетеров, инъекции, забор анализов. С помощью федерального проекта «ИВЛ на дому» 2 детей в Республики Бурятия получают данное медицинское вмешательство в домашних условиях. Осуществляется и социальная поддержка семей, которые включают в себя вопросы образования ребенка, обеспечение лекарственными препаратами и средствами технической реабилитации, оформление социальных пособий и юридические консультации. Также при патронажной службе организовано волонтерское движение.

Заключение: амбулаторная паллиативная помощь детям в Республики Бурятия организована 3 года назад, но уже имеет положительные результаты: способность организации медицинской и социальной помощи нуждающимся на дому, способность облегчить страдания пациента и членов его семьи.

Дальнейшие перспективы службы направлены на создание республиканского регистра детей, нуждающихся в паллиативной помощи, что позволит разработать единый алгоритм организации оказания паллиативной медицинской помощи на территории республики. Организация учебно-методической помощи будет способствовать расширению географии распространения этого вида помощи в отдаленных районах Республики Бурятия.

Лumepamypa

1. Об основах охраны здоровья граждан в Российской Федерации: федеральный закон от 21.11.2011 Г. № 323-Ф3. URL: http://www.consultant. $\mathrm{ru} /$ document/cons_doc_LAW_148786

2. Д. И. Зеленская. Паллиативная помощь в педиатрии // Российский вестник перинатологии и педиатрии. 2016. № 6. С. 61-66.

\section{DEVELOPMENT OF OUTPATIENT PALLIATIVE CARE \\ FOR CHILDREN AND ADOLESCENTS IN THE REPUBLIC OF BURYATIA}

Larisa $V$. Zhdanova

Candidate of Medical Sciences, Associate Professor,

Dorzhi Banzarov Buryat State University

24a Smolina St., Ulan-Ude 670000, Russia

E-mail: 1.zhdanova@mail.ru 
Л. В. Жданова $u \mathrm{~m}$. $\partial$. Развитие амбулаторной паллиативной помощи детям и подросткам в Республике Бурятия

Olga A. Lebedeva

Head of the Department of Palliative Care for Children of the City Polyclinic №2

23, Geologicheskaya Str., Ulan-Ude, 670031 Russia

Tel .: +73012230399

E-mail: rusinovata@gp2rb.ru

Victoria V. Kolmakova

Chief Physician of the City Polyclinic №2

23, Geologicheskaya Str., Ulan-Ude, 670031 Russia

Tel .: +73012235098

E-mail: priem@gp2rb.ru

Tatyana A. Rusinova

Deputy Head Doctor for the provision of medical care to children of the City Polyclinic№2

23, Geologicheskaya Str., Ulan-Ude, 670031 Russia

Tel .: +73012230399

E-mail: rusinovata@gp2rb.ru

The purpose of the research was to study the performance indicators of the palliative medical care for children staying at home in the Republic of Buryatia. The work is based on a report on the work of the patronage of palliative care for children in the City outpatient hospital №2. There are 4955 disabled children in the Republic of Buryatia, 5\% of them need palliative care. Today, 114 children are serving the field service. Most of children are from 0 to 14 years old. The largest number of cases $(80 \%)$ include the diseases of the nervous system. The second place is given to congenital malformations and genetic pathology. With cancer pathology, children receive specialized palliative care in the Republican Children's Clinical Hospital. In 2018, there were 34 children with indications to provide this type of medical care. During the years of the patronage service 14 children died. Keywords: palliative care, children, cancer pathology, outpatient hospital. 